EXTENDED REPORT

\title{
Expression and regulation of cryopyrin and related proteins in rheumatoid arthritis synovium
}

\author{
S Rosengren, H M Hoffman, W Bugbee, D L Boyle
}

See end of article for authors' affiliations

\section{Correspondence to:} Mr D L Boyle, UCSD School of Medicine, 0656 , 9500 Gilman Drive, La Jolla California 920930656, USA; dboyle@ucsd. edu

Accepted 24 September 2004 Published Online First 21 October 2004

\begin{abstract}
Background: Rheumatoid arthritis (RA) synovium is characterised by enhanced NF- $\mathrm{B} B$ activity and proinflammatory cytokines. Cryopyrin (CIAS-1, NALP-3, PYPAF-1) has been shown to regulate NF-KB and caspase-1 activation.

Objective: To study the expression of cryopyrin, its effector molecule ASC, and its putative antagonist pyrin in RA and osteoarthritis (OA) synovium, and the main two cellular constituents of synovial lining, cultured fibroblast-like synoviocytes (FLS) and macrophages.

Methods: FLS and macrophages were cultured in the presence of inflammatory mediators. Real time polymerase chain reaction was used to quantify message levels in synovial biopsy specimens and cells. In situ hybridisation was employed to localise expression of cryopyrin mRNA.

Results: Cryopyrin mRNA was raised in RA synovium and detected in both lining and sublining regions. FLS from RA and OA tissue expressed low baseline levels of cryopyrin transcripts that were induced by tumour necrosis factor $\alpha$ (TNF $\alpha$ ). In contrast, macrophages differentiated in vitro expressed relatively high cryopyrin levels, which were further induced by $T N F \alpha$, but not by interleukin 1 $\beta$. ASC mRNA levels were comparable in RA and OA tissue, FLS, and macrophages, and were depressed by TNF $\alpha$ in macrophages. Pyrin expression was higher in RA synovium than in OA tissue, and virtually undetectable in FLS but high in macrophages where it was unchanged by TNF $\alpha$ treatment.

Conclusion: These results suggest that enhanced cryopyrin levels in RA synovium are due to a greater numbers of tissue macrophages, and demonstrate transcriptional regulation of cryopyrin in a chronic inflammatory disease.
\end{abstract}

$\mathrm{R}$ heumatoid arthritis (RA) is a common inflammatory disease, yet its pathogenesis remains incompletely understood. Synovial tissue from patients with RA contains raised levels of cytokines, such as tumour necrosis factor $\alpha(\mathrm{TNF} \alpha)$ and interleukin (IL) $1 \beta$, and metalloproteinases, such as matrix metalloproteinase (MMP)-1 and MMP-3. The transcription factor NF- $\kappa \mathrm{B}$, which regulates cytokine and MMP expression, is highly activated in RA synovium. ${ }^{1-5}$ Hence, pathways that influence NF- $\kappa B$ activation are of interest as potential therapeutic targets for RA.

A family of inflammatory proteins, characterised by the presence of a nucleotide binding oligomerisation domain (NOD), was recently identified. ${ }^{6}$ Among them, cryopyrin (PYPAF-1, NALP-3) is a new protein, encoded by the gene CIASI, with putative inflammatory function. ${ }^{7}$ Mutations in CIASI are present in a family of autoinflammatory diseases..$^{7-11}$ Common features of these disorders are atypical urticarial rash and rheumatic manifestations (arthralgia, and osseus overgrowth in severe forms). Cryopyrin exerts its function through ASC (apoptosis associated speck-like protein containing a caspase recruitment domain (CARD)), which functions as an adaptor to downstream pathways. ${ }^{12}{ }^{13}$ When cryopyrin and ASC are co-expressed, they activate caspase$1,{ }^{14}{ }^{15}$ which cleaves pro-ILl $\beta$ to ILl $\beta$, and up regulates NF- $\kappa B$ activity. ${ }^{12}{ }^{16}{ }^{17}$ Similar results are observed when ASC is coexpressed with other NOD proteins. ${ }^{18-20}$ Pyrin, the protein mutated in familial Mediterranean fever, ${ }^{21}$ may inhibit cryopyrin-ASC interactions. ${ }^{13}$

Cryopyrin and pyrin mRNA are mainly expressed in leucocytes. ${ }^{72} 22$ ASC is more widely distributed..$^{23}$ However, expression patterns of cryopyrin in human inflammatory diseases have not been studied. Because RA synovium is characterised by NF- $\kappa B$ activation and raised levels of cytokines, the expression of cryopyrin and related proteins was studied in RA and OA synovial tissues as well as in synovial cell subtypes.

\section{PATIENTS AND METHODS}

\section{Patients and tissue preparation}

Hip or knee synovial tissue was collected at the time of arthroplasty from patients with RA or osteoarthritis (OA) after obtaining informed consent and University of California, San Diego Institutional Review Board approval. Tissues included 12 knees and two hips from patients with OA; and eight knees, four hips, one shoulder, and one metacarpophalangeal joint from patients with RA. Synovial fragments $\left(1-2 \mathrm{~mm}^{2}\right)$ were excised on ice and immediately frozen in RNAStat-60 reagent (Tel-Test, Friendswood, TX). At least six synovial fragments from each joint were analysed together to reduce sampling error, ${ }^{24}$ and only one joint for each patient was analysed. Lining and sublining portions were microdissected from seven RA and seven OA cryosectioned synovial tissues as previously described. ${ }^{25}$

\section{Cell isolation and culture}

Fibroblast-like synoviocytes (FLS) were prepared and cultured as previously described ${ }^{26}$ and used at passages 3-6. Before experiments, FLS were cultured under conditions of

Abbreviations: ANOVA, analysis of variance; ASC, apoptosis associated speck-like protein containing a CARD; CARD, caspase recruitment domain; DIG, digoxygenin; FCS, fetal calf serum; FLS, fibroblast-like synoviocytes; GAPDH, glyceraldehyde-3-phosphate dehydrogenase; GFP, green fluorescent protein; IL, interleukin; LPS, lipopolysaccharide; M-CSF, monocyte-colony stimulating factor; MMP, matrix metalloproteinase; NOD, nucleotide binding oligomerisation domain; OA, osteoarthritis; PBMC, peripheral blood mononuclear cells; qPCR, quantitative polymerase chain reaction; RA, rheumatoid arthritis; REU, relative expression units; TNF $\alpha$, tumour necrosis factor $\alpha$ 

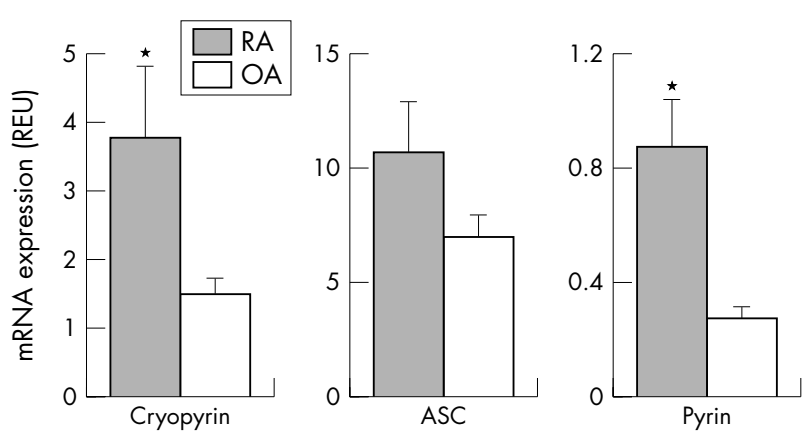

Figure 1 Expression of cryopyrin, ASC, and pyrin mRNA in synovial tissue from patients with RA and OA undergoing joint replacement surgery, as determined by real time qPCR. REU (relative expression units) data are standardised to known dilutions of PBMC CDNA and normalised by GAPDH to control for cellularity. Results are from 14 patients for each group. ${ }^{*} p<0.05$ by Student's $t$ test on log transformed data. Both the cryopyrin and pyrin message was significantly raised in RA.

reduced serum ( $1 \%$ fetal calf serum (FCS)) for 2-3 days. Macrophage-like cells were generated from healthy donor peripheral blood mononuclear cells (PBMC) using a modification of previously reported methods. ${ }^{27}$ Briefly, 5 million $\mathrm{PBMC} /$ well were allowed to adhere in 24 well plates at $37^{\circ} \mathrm{C}$ for 3 hours. Non-adherent cells were aspirated, and remaining monocytes were cultured in RPMI containing antibiotics, $10 \%$ FCS, and $50 \mathrm{ng} / \mathrm{ml}$ of monocyte-colony stimulating factor (M-CSF; R\&D Systems, Minneapolis, MN) for 5 days to encourage maturation towards a macrophage-like phenotype. FLS and macrophages were activated with TNF $\alpha$ (R\&D Systems) at $50 \mathrm{ng} / \mathrm{ml}$, and macrophages by lipopolysaccharide (LPS $10 \mathrm{ng} / \mathrm{ml}$; E coli 0111:B4; Chemicon, Temecula, CA) or ILl $\beta$ ( $2 \mathrm{ng} / \mathrm{ml}, \mathrm{R} \& D$ Systems). Incubations were terminated by lysis with RNAStat-60.

\section{Real time quantitative PCR analysis}

Synovial and cell cDNA were prepared as described by Boyle et $a l^{24}$ and subjected to real time quantitative PCR (qPCR) to measure cryopyrin and ASC transcripts using SYBR Green Universal Master Mix (Applied Biosystems). Primers were as follows: cryopyrin-forward, 5'AAAGAGATGAGCCGAAGTGGG, used at $400 \mathrm{nmol} / \mathrm{l}$, reverse, 5'-TCAATGCTGTCTTCCTGGCA, used at $50 \mathrm{nmol} / \mathrm{l}$, product $79 \mathrm{bp}$; ASC-forward, 5'-GCGAGGGTCACAAACCTTG, reverse, 5'-CTGCTCATCCGTCAGGACCT, both used at $200 \mathrm{nmol} / \mathrm{l}$, product $66 \mathrm{bp}$. The specificity of qPCR was confirmed by restriction fragment length analysis, melting point, and molecular weight of amplicons. MMP-1 qPCR has been described previously. ${ }^{24}$ Pyrin, ILI $\beta$, MMP-9, and glyceraldehyde-3-phosphate dehydrogenase (GAPDH) were quantified by TaqMan PCR using predeveloped reagents (Applied Biosystems). Resulting threshold cycle $\left(C_{t}\right)$ data were normalised to standard curves constructed from

Table 1 Expression of cryopyrin and ASC in RA synovial lining and sublining

\begin{tabular}{llll}
\hline Gene product & $\begin{array}{l}\text { RA synovial lining } \\
\text { (REU)* }\end{array}$ & $\begin{array}{l}\text { RA synovial } \\
\text { sublining (REU) }\end{array}$ & p Value \\
\hline Cryopyrin & $2.50(0.74)$ & $4.44(1.70)$ & 0.56 \\
ASC & $3.97(0.60)$ & $4.28(0.73)$ & 0.99 \\
Pyrin & $0.68(0.23)$ & $0.83(0.27)$ & 0.70 \\
\hline
\end{tabular}

*Data are expressed as mean (SEM) of GAPDH normalised REU from two microdissected regions each of seven (cryopyrin and ASC) or four (pyrin) RA synovial cryosections. There was no significant difference in gene expression between lining and sublining regions for any transcript. concanavalin A stimulated PBMC CDNA, ${ }^{24}$ yielding cell equivalents. The ratio between the specific cytokine and GAPDH cell equivalents (relative expression units (REU)) is reported.

\section{Preparation and transfection of CIAS1-GFP fusion construct}

A CIASI green fluorescent protein (GFP) fusion protein construct was amplified from full length CIASI $\mathrm{CDNA}^{7}$ in a TOPO cloning vector, and ligated into pEGFP-Nl (Clontech, Palo Alto, CA). CHO cells were transiently transfected with $0.2 \mu \mathrm{g}$ of CIASI-GFP DNA using Fugene6 transfection reagent (Roche Applied Science, Indianapolis, IN) added to $10^{5}$ cells grown in four chamber culture slides for 24 hours.

\section{Riboprobe synthesis}

A 193 bp fragment (position 257 to 449 ) was generated by PCR from full length CIASI and subcloned into pBluescript II KS(-) (Stratagene, La Jolla, CA). This fragment was chosen because of limited homology with other related proteins. The MMP-3 plasmid has been described previously. ${ }^{28}$ Antisense and sense RNA probes were generated using T7 and T3 (cryopyrin) or T3 and SP6 (MMP-3) RNA polymerases and digoxygenin (DIG) labelled UTP (Roche). MMP-3 probes were briefly alkaline hydrolysed. The resulting riboprobe amount was estimated by dot blot (anti-DIG-AP, 1:5000 dilution, Roche) followed by 5-bromo-4-chloro-3-indoyl phosphate (BCIP)/nitroblue tetrazolium (NBT) substrate (Vector Laboratories, Burlingame, CA).

\section{In situ hybridisation}

Cryopyrin and MMP-3 mRNA were visualised in RA synovial paraformaldehyde fixed cryosections by in situ hybridisation. The blocking/acetylation, prehybridisation, and hybridisation procedures have been described previously, ${ }^{28}$ except that $30 \mathrm{ng}$ of DIG labelled riboprobe was used for each section. Slides were washed with three changes of $2 \times$ saline sodium citrate $+50 \%$ formamide at $50{ }^{\circ} \mathrm{C}, 50$ minutes total, blocked using 1\% sheep serum in Tris buffered saline, and incubated overnight with anti-DIG-AP at 1:200 in blocking solution, developed using BCIP/NBT substrate, and counterstained with methyl green.

\section{Data analysis}

All qPCR results are shown as mean (SEM) of GAPDH normalised REU. Tissue expression data were log transformed to acquire normal distributions as detected by Shapiro-Wilk's W test for goodness of fit. Differences in gene expression were detected by Student's $t$ test, or analysis of variance (ANOVA) followed by Dunnett's post hoc test when appropriate. Time series data were analysed using a repeated measures design. A value of $\mathrm{p}<0.05$ was considered significant.

\section{RESULTS \\ Enhanced expression of cryopyrin and pyrin in RA synovium}

The expression of cryopyrin, its effector protein (ASC), and its putative antagonist (pyrin) was examined in RA and OA synovium. All three gene products were readily measurable by qPCR in all tissues with the exception of one OA tissue which lacked detectable cryopyrin mRNA. Cryopyrin and pyrin expression was significantly higher in RA synovium $(p<0.030$ and $p<0.0025$ for cryopyrin and pyrin, respectively), whereas ASC levels were similar in RA and OA tissues $(p<0.24)$ (fig 1$)$. Most synovia were from knees, but when only knee tissue data were included in the analysis $(n=8$ and 12 for RA and OA, respectively) the RA to OA expression ratios were not markedly different from those obtained with the whole dataset (ratio $=3.14,1.89$, and 3.22 for cryopyrin, ASC, and pyrin, respectively). 


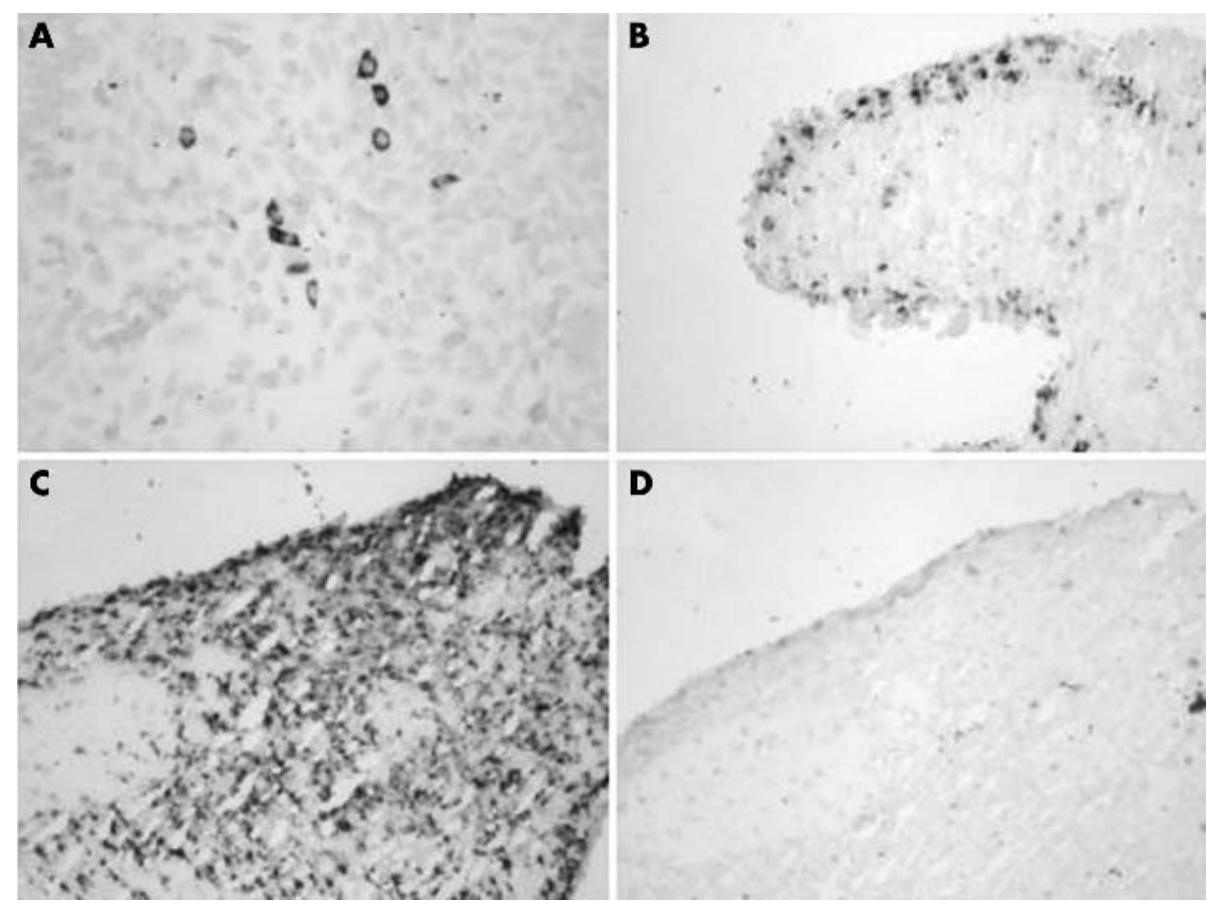

Figure 2 Detection of cryopyrin mRNA in synovial tissue by in situ hybridisation. (A) CHO cells transfected with a cryopyrin-GFP fusion construct and hybridised with cryopyrin antisense probe to demonstrate its specificity. No signal was obtained with cryopyrin sense probe (not shown). (B) RA synovium hybridised with MMP-3 antisense probe shows typical lining distribution. MMP-3 sense probe did not hybridise (not shown). (C) Cryopyrin mRNA is expressed in both lining and sublining in RA synovium as shown by the antisense probe. (D) The cryopyrin sense probe did not hybridise to RA synovium (serial section, same area as in C).

\section{Expression of cryopyrin in RA synovial lining and sublining}

To determine whether cryopyrin is preferentially expressed in synovial lining or sublining, regions of interest were microdissected from frozen synovial sections and subjected to qPCR. In OA tissues, cryopyrin message was undetectable or barely detectable in whole tissue sections; hence, analysis of microdissected regions was not attempted. In contrast, all RA synovial sections as well as most lining and sublining portions contained detectable levels of cryopyrin mRNA. Interestingly, there was no difference in cryopyrin expression between lining and sublining regions (table 1). Similarly, ASC and pyrin were present at similar levels in RA synovial lining and sublining (table 1 ).

These findings were confirmed by in situ hybridisation in RA synovium. Antisense cryopyrin probe specificity was demonstrated by its hybridisation to $\mathrm{CHO}$ cells transfected with a cryopyrin-GFP construct (fig $2 \mathrm{~A}$ ) at a percentage similar to that observed for GFP protein expression by fluorescence microscopy (not shown). The antisense probe did not hybridise to cells transfected with GFP only, and the sense probe hybridised to neither. MMP-3 expression in synovial sections was used as a control for mRNA quality, and was clearly localised to the synovial lining as expected (fig $2 \mathrm{~B}$ ). On the other hand, cryopyrin antisense probe bound to cells in both lining and sublining regions (fig 2C). No signal was obtained with the cryopyrin sense probe (fig 2D). Taken together, these results show that cryopyrin is expressed in both lining and sublining cells of RA synovium.

\section{Expression of cryopyrin and related proteins in FLS is induced by TNF $\alpha$}

In view of the expression of cryopyrin in the intimal lining, regulation of cryoprin was evaluated in cultured FLS by qPCR. The cryopyrin message was detectable at similar low baseline levels, in RA and OA FLS lines (fig 3A) and was independent of whether cells were cultured in 10\% or 1\% FCS (data not shown). TNF $\alpha$ transiently induced cryopyrin in both RA and OA FLS (fig 3A). There was no difference in cryopyrin expression between RA and OA FLS. To ensure that the FLS remained fully activated throughout the study, MMP-1 mRNA levels were assessed and were shown to be persistently raised by TNF $\alpha$ (fig 3D).

At baseline, ASC RNA transcripts were present in both RA and OA FLS at levels comparable to those in synovial tissue (fig 3B). Intriguingly, $\mathrm{TNF} \alpha$, significantly increased ASC mRNA levels in RA FLS but not in OA cells (fig 3B). The pyrin message was low or undetectable in all baseline FLS cultures, but was induced by TNF $\alpha$ to the same extent in both RA and OA FLS (fig 3C), although due to high variability the increase was not statistically significant. Hence, cryopyrin mRNA is present in very low baseline levels in FLS, but is inducible with TNF $\alpha$. On the other hand, ASC message is readily detectable at baseline and increases only in RA FLS after incubation with TNF $\alpha$.

\section{Altered expression of cryopyrin and related proteins in macrophages by TNFa}

Recently published data indicated that primary human monocytes increase the cryopyrin message in response to LPS and TNF $\alpha .{ }^{29}$ To extend these findings to macrophage-like cells, adherence enriched monocytes were differentiated with M-CSF and 10\% FCS for 5 days and analysed by qPCR. Baseline cryopyrin levels were similar to those observed in synovial tissue, and were increased by LPS or TNF $\alpha$, whereas IL1 $\beta$ had no effect (fig 4A). As a control for activation, ILl $\beta$ message was significantly induced by both LPS and TNF $\alpha$. IL1 $\beta$ message did not increase significantly after stimulation with ILl $\beta$ cytokine. However, MMP-9 (another macrophage activation marker) mRNA significantly increased after ILl $\beta$ stimulation (REU $=15.3$ (3.6) and 26.8 (2.2) for control and ILl $\beta$ stimulated, respectively, $p=0.05)$, indicating that 

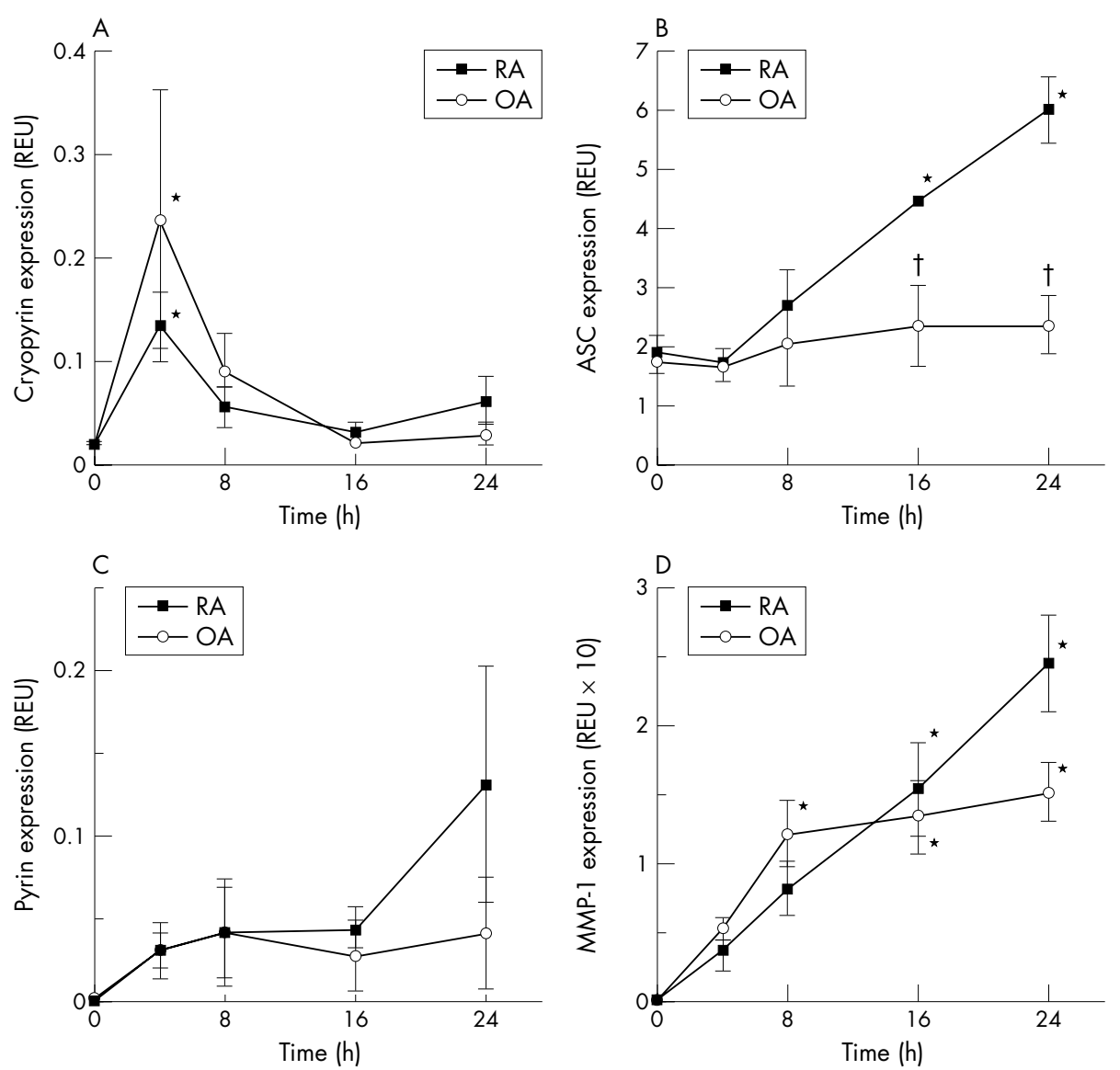

Figure 3 Expression of cryopyrin (A), ASC (B), and pyrin (C) mRNA in FLS after stimulation with TNF $\alpha(50 \mathrm{ng} / \mathrm{ml})$ at time zero. Results are from real time qPCR studies of three cell lines each and are expressed as GAPDH normalised REU as in fig 1 legend. ${ }^{*} p<0.05$ from time zero and $t p<0.05$ between RA and OA, by repeated measures ANOVA. (A) Expression of cryopyrin was transiently raised in both RA and OA FLS. (B) ASC was up regulated in RA but not OA FLS. (C) Pyrin was not detectable at baseline but was induced. (D) As a control, continuous MMP-1 expression demonstrates that FLS were fully activated.

macrophage activation was achieved with all three stimuli. ASC message levels, which were similar to those in synovial tissue at baseline, declined upon stimulation with LPS or TNF $\alpha$, whereas IL1 $\beta$ again had no effect (fig 4B). Finally, pyrin mRNA remained unchanged after activation with either cytokine, whereas LPS stimulated its synthesis (fig 4B).

Macrophages were then stimulated with TNF $\alpha$ for $1-$ 24 hours, and gene expression was analysed. Interestingly, expression of cryopyrin increased rapidly, then declined, then rose again in a biphasic response (fig 5A). In the same experiment, ILl $\beta$ message remained up regulated for the entire incubation time with TNF $\alpha$ (fig 5D), suggesting that the macrophages were in a continuous state of activation. The earlier observed drop in ASC expression became statistically significant at 8 and 18 hours (fig 5B). However, pyrin mRNA levels remained unchanged throughout the experiment (fig 5C). These results demonstrate that the cryopyrin message is inducible by TNF $\alpha$ but not by ILl $\beta$ in macrophages, whereas expression of its effector ASC is lowered and its putative antagonist pyrin remains unchanged.

\section{DISCUSSION}

Cryopyrin is a recently identified member of a family of proteins (designated as NOD, NALP, or CATERPILLAR) which modulate pathways crucial to inflammation and apoptosis, such as NF- $\kappa \mathrm{B}$ and caspase activation. ${ }^{6}$ This protein family is characterised by the presence of a pyrin or CARD domain, a central NOD domain, and C-terminal leucin-rich repeats. ${ }^{6}$ Proteins containing a CARD can interact directly with caspases, whereas pyrin domain-containing proteins such as cryopyrin require the adaptor protein ASC, which contains a pyrin linked to a CARD, as an intermediary.

In the current study, expression of cryopyrin and related proteins in late stage rheumatoid synovitis were characterised. Of interest, cryopyrin levels were enhanced in RA synovium compared with those in OA tissue. OA synovium was used for comparison because of its comparable cellularity to RA as well as its availability. These results suggest either that the resident cells contain raised cryopyrin message levels, or alternatively, that an influx of cells preferentially expressing this gene occurs in RA synovium. To elucidate this issue, regional differences in cryopyrin expression were first examined by qPCR on microdissected fragments and by in situ hybridisation. By both methods, cryopyrin expression was observed in synovial lining as well as sublining, whereas the control mRNA species, MMP-3, was found mostly in lining by in situ hybridisation as earlier described. ${ }^{28}$ The cells expressing cryopyrin in the intimal lining could be macrophages and/or FLS (that is, type I and/ or type II synoviocytes). Infiltrating macrophages, resident fibroblasts, or other mononuclear cells might contribute to sublining expression.

In tissue distribution studies using northern blot, significant cryopyrin expression was restricted to leucocytes. ${ }^{7}$ By qPCR, cryopyrin message was most abundant in monocytes. ${ }^{12}$ In the present studies, cryopyrin mRNA was found in both FLS and in monocyte derived macrophages. However, 

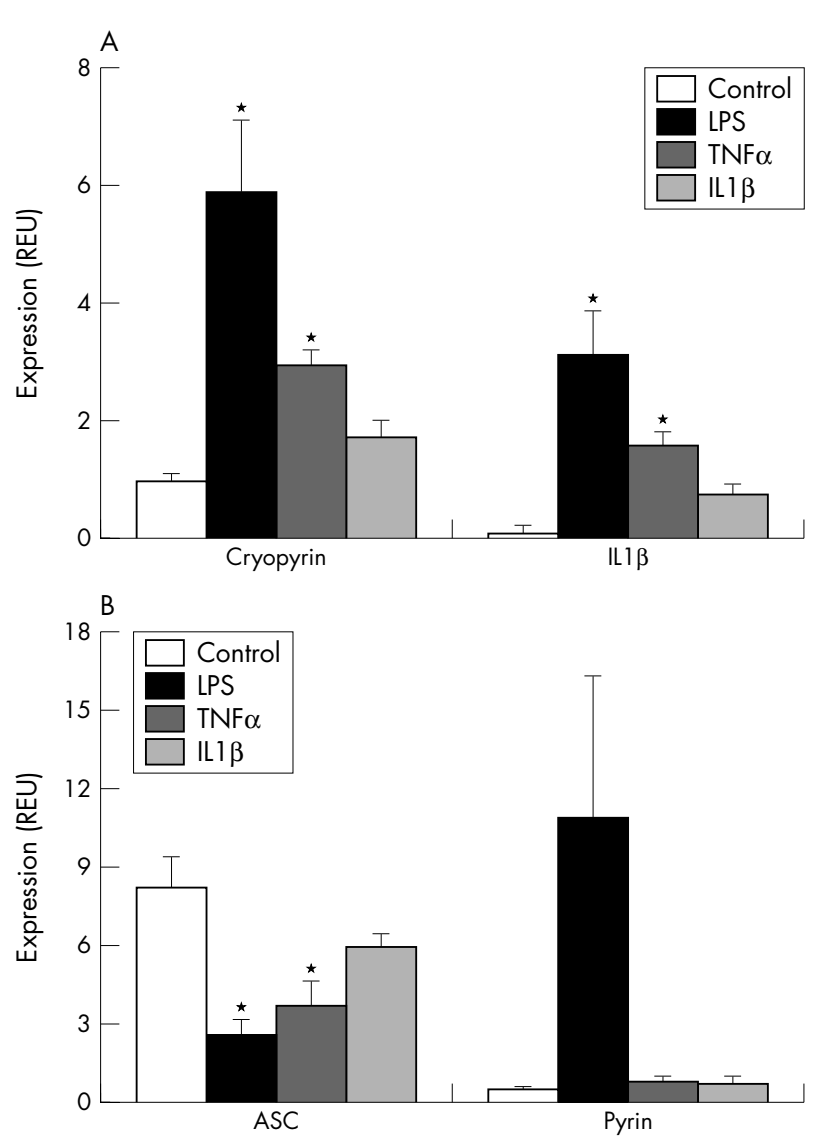

Figure 4 Expression of (A) cryopyrin, (B) ASC and pyrin mRNA in macrophage-like cells differentiated from healthy donor monocytes by 5 day culture in M-CSF and serum. Cells were treated with LPS (10 ng/ $\mathrm{ml})$, TNF $\alpha(50 \mathrm{ng} / \mathrm{ml})$, or IL1 $\beta(2 \mathrm{ng} / \mathrm{ml})$ for 18 hours before real time qPCR analysis. Results are from three donors and expressed as GAPDH normalised REU as in the legend to fig $1 .{ }^{*} p<0.05$ compared with control, untreated cells by single ANOVA, and Dunnett's post hoc test. The cryopyrin message was induced by LPS and TNF $\alpha$, whereas ASC message levels decreased under the same conditions. Pyrin was only raised by LPS but not by either cytokine. The IL1 $\beta$ message was significantly up regulated by LPS and TNF $\alpha(A)$, whereas ILI $\beta$ itself up regulated MMP-9 expression (see text), indicating macrophage activation in all cases.

macrophages contained substantially more cryopyrin message for each cell than FLS (compare fig 3 with figs 4 and 5), at levels comparable to those in synovial tissue. Hence our results are most consistent with the notion that the high cryopyrin levels in RA tissue are due to increased levels of tissue macrophages.

The rheumatoid synovium is characterised by high levels of cytokines, mostly of macrophage and fibroblast origin. ${ }^{30}$ There has been significant discussion about the evolution and transformation of the rheumatoid synovium during the course of disease. We evaluated synovia from established disease collected at the time of arthroplasty. Among the cytokines, TNF $\alpha$ contributes significantly to disease progression as demonstrated by the clinical success of TNF inhibitors in the treatment of RA. A recent study showed that TNF $\alpha$ rapidly induces cryopyrin message in human monocytes. ${ }^{29}$ In our study we extended these findings to differentiated macrophages and also showed that IL1 $\beta$, another prevalent cytokine in RA, does not up regulate cryopyrin. This might indicate a requirement for $\mathrm{TNF} \alpha$ signal transduction pathways, although LPS (which also induced cryopyrin mRNA) signalling occurs at least partly through MyD88, an ILI $\beta$ signalling molecule, suggesting that the LPS response might be due to activation of alternative pathways. Surprisingly, $\mathrm{TNF} \alpha$ also increased cryopyrin mRNA levels in FLS. To our knowledge this is the first time that a cell type other than leucocytes has been shown to regulate a NOD protein in response to a cytokine. The difference in expression patterns in the two cell types is intriguing: in FLS, expression is transient, whereas in macrophages two phases of expression are observed. It is currently unclear how these results of relatively short term expression in both cell types relate to cryopyrin levels in a condition characterised by continuing cytokine secretion such as RA.

The adaptor protein of cryopyrin, ASC, was previously identified in many cell types and organs. ${ }^{23}$ In our hands, ASC expression in FLS and macrophages was similar, and comparable to that in synovial tissue. Thus, both FLS and macrophages probably contribute to ASC expression in synovium. In response to $\mathrm{TNF} \alpha$, an intriguing difference between RA and OA FLS was found in that RA cells up regulated ASC message whereas OA FLS did not, but both cell types produced high levels of MMP-1, indicating full activation. Even more unexpectedly, macrophages down regulated ASC message levels by $50-70 \%$ in response to TNF $\alpha$ while increasing their levels of mRNA coding for ILl $\beta$ (and cryopyrin). This appears to indicate differential regulation of ASC by inflammatory mediators in FLS and macrophages.

The protein pyrin contains a pyrin domain, linked to a C-terminal sequence unique among pyrin domain proteins. ${ }^{31}$ In earlier studies, high pyrin mRNA levels were found in neutrophils and monocytes, ${ }^{22}$ and also identified in peritoneal and skin fibroblasts ${ }^{32}$ as well as in FLS $^{33}$ where pyrin mRNA was inducible by TNF $\alpha$. In the present set of studies, pyrin expression in RA synovium was raised about threefold over the level in OA synovial tissue. Baseline levels in FLS were virtually undetectable, and $\mathrm{TNF} \alpha$ appeared to induce expression to a variable extent. In contrast, macrophages contained readily detectable pyrin message that remained constant in the presence of TNF $\alpha$ (although it was induced by LPS). A comparison of tissue, macrophage, and FLS expression levels of pyrin (figs 1, 3, and 5) suggests that FLS contribute only a minor portion of pyrin mRNA in RA synovium. Hence, as for cryopyrin, the data are consistent with the notion that the raised pyrin expression in RA synovium is due to higher macrophage numbers.

Several groups have studied interaction among cryopyrin, pyrin, and ASC in plasmid overexpression systems. Pyrin was shown to compete with caspase-1 for binding to ASC, thereby exerting a modulating effect on IL1 $\beta$ production. ${ }^{34}$ Pyrin has also been proposed as an antagonist of cryopyrin-ASC interactions. ${ }^{13}$ Thus, pyrin might interfere with cryopyrin mediated cytokine production at several points in the signalling cascade. However, when cryopyrin was overexpressed in the absence of ASC, it reduced TNF $\alpha$ stimulated NF- $\kappa$ B translocation $^{29}$ as well as ILl $\beta$ secretion. ${ }^{14}$ The physiological relevance of these findings is unclear because both cryopyrin and ASC are present in cells of myeloid lineage. In fact, when ASC was added to cryopyrin, ILl $\beta$ secretion was instead enhanced in a cryopyrin plasmid doseresponse manner. ${ }^{14}$

These data suggest that the outcome of interactions among cryopyrin, ASC, and pyrin depends on their relative balance. Hence, our current observations of differential regulation of cryopyrin and ASC mRNA levels in macrophages may have significance. Whereas the early cryopyrin peak occurs while ASC levels remain steady, the later phase of cryopyrin expression coincides with a significant drop in ASC mRNA. It is tempting to speculate that the lowered ASC levels allow cryopyrin to exert its inhibitory function, although further studies are needed to understand the precise nature of such 

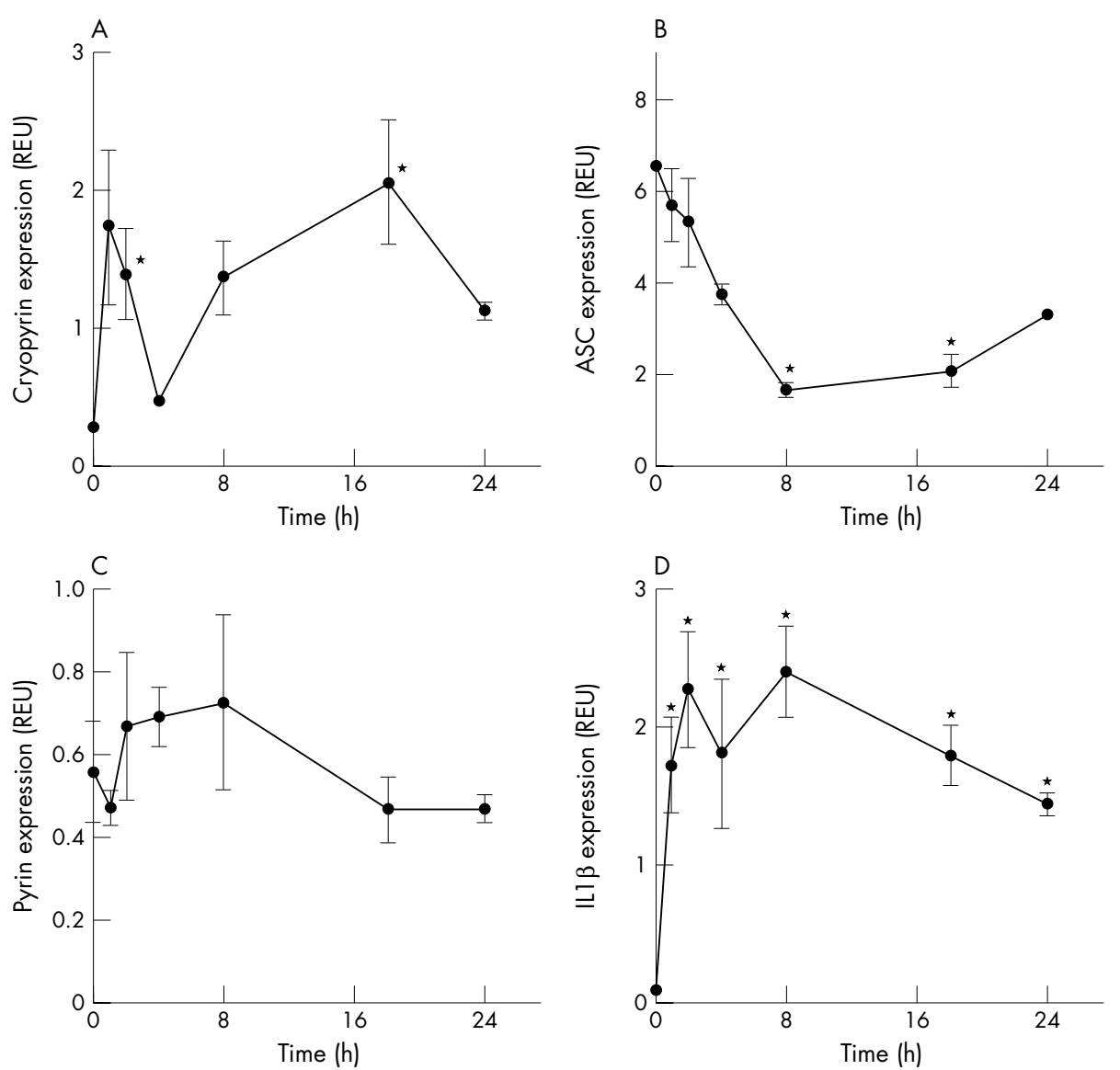

Figure 5 Time course of mRNA expression in monocyte derived, macrophage-like cells in response to treatment with TNF $\alpha$ ( $50 \mathrm{ng} / \mathrm{ml})$. Results are from three donors and expressed as GAPDH normalised REU as in the legend to fig. 1. * $p<0.05$ from time zero by repeated measures ANOVA. (A) Cryopyrin message was induced in two phases, whereas (B) ASC levels fell. (C) Pyrin remained unaltered. (D) Cells were fully activated as indicated by continuous expression of ILI $\beta$.

interactions. The identification of several cryopyrin-like proteins within the human genome ${ }^{35}$ suggests that other factors may influence the function of cryopyrin and ASC.

In conclusion, cryopyrin and pyrin mRNA were raised in RA synovium in comparison with OA synovium. Cryopyrin was equally expressed in synovial lining and sublining and identified within cells in both areas by in situ hybridisation. Both FLS and macrophages in vitro expressed cryopyrin, but macrophages contained much higher levels, both at baseline and after TNF $\alpha$ induction. mRNA levels for the adaptor, ASC, were similar among RA and OA synovium, FLS, and macrophages. On the other hand, the putative cryopyrin antagonist, pyrin, was virtually undetectable in FLS but expressed in macrophages. These data demonstrate for the first time cryopyrin regulation in a chronic inflammatory condition and set the stage for future studies of the functional significance of cryopyrin, ASC, and pyrin in RA.

\section{ACKNOWLEDGEMENTS}

We thank Suzanne Beal for help with preparation of in situ hybridisation slides, and Justin Anderson and James Mueller for assistance with cloning, transfections, and monocyte isolation.

\section{Authors' affiliations}

S Rosengren, H M Hoffman, D L Boyle, Division of Rheumatology, Allergy and Immunology, Department of Medicine, UCSD School of Medicine, La Jolla, CA, USA

W Bugbee, Department of Orthopedics, UCSD School of Medicine, La Jolla, CA, USA

\section{REFERENCES}

1 Asahara H, Asanuma M, Ogawa N, Nishibayashi S, Inoue H. High DNAbinding activity of transcription factor NF-kappa B in synovial membranes of patients with rheumatoid arthritis. Biochem Mol Biol Int 1995;37:827-32.

2 Marok R, Winyard PG, Coumbe A, Kus ML, Gaffney K, Blades S, et al. Activation of the transcription factor nuclear factor-kappaB in human inflamed synovial tissue. Arthritis Rheum 1996;39:583-91

3 Han Z, Boyle DL, Manning AM, Firestein GS. AP-1 and NF-kappaB regulation in rheumatoid arthritis and murine collagen-induced arthritis. Autoimmunity 1998;28:197-208.

4 Bondeson J, Foxwell B, Brennan F, Feldmann M. Defining therapeutic targets by using adenovirus: blocking NF-kappaB inhibits both inflammatory and destructive mechanisms in rheumatoid synovium but spares anti-inflammatory mediators. Proc Natl Acad Sci USA 1999;96:5668-73.

5 Aupperle K, Bennett B, Han Z, Boyle D, Manning A, Firestein G. NF-kappa B regulation by I kappa $B$ kinase- 2 in rheumatoid arthritis synoviocytes. J Immunol 2001;166:2705-11.

6 Inohara N, Nunez G. NODs: intracellular proteins involved in inflammation and apoptosis. Nat Rev Immunol 2003;3:371-82.

7 Hoffman HM, Mueller JL, Broide DH, Wanderer AA, Kolodner RD. Mutation of a new gene encoding a putative pyrin-like protein causes familial cold autoinflammatory syndrome and Muckle-Wells syndrome. Nat Genet 2001;29:301-5.

8 Hoffman HM, Wanderer AA, Broide DH. Familial cold autoinflammatory syndrome: phenotype and genotype of an autosomal dominant periodic fever. $J$ Allergy Clin Immunol 2001;108:615-20.

9 Dode C, Le Du N, Cuisset L, Letourneur F, Berthelot JM, Vaudour G, et al. New mutations of CIAS1 that are responsible for Muckle-Wells syndrome and familial cold urticaria: a novel mutation underlies both syndromes. Am J Hum Genet 2002;70: 1498-506.

10 Aksentijevich I, Nowak M, Mallah M, Chae JJ, Watford WT, Hofmann SR, et al. De novo CIASI mutations, cytokine activation, and evidence for genetic heterogeneity in patients with neonatal-onset multisystem inflammatory disease (NOMID): a new member of the expanding family of pyrin-associated autoinflammatory diseases. Arthritis Rheum 2002;46:3340-8.

11 Feldmann J, Prieur AM, Quartier P, Berquin P, Certain S, Cortis E, et al. Chronic infantile neurological cutaneous and articular syndrome is caused by 
mutations in CIAS1, a gene highly expressed in polymorphonuclear cells and chondrocytes. Am J Hum Genet 2002;71:198-203.

12 Manji GA, Wang L, Geddes BJ, Brown M, Merriam S, Al-Garawi A, et al. PYPAF1, a pyrin-containing Apaf1-like protein that assembles with ASC and regulates activation of NF-kappa B. J Biol Chem 2002;277:1 1570-5.

13 Dowds TA, Masumoto J, Chen FF, Ogura Y, Inohara N, Nunez G. Regulation of cryopyrin/Pypafl signaling by pyrin, the familial Mediterranean fever gene product. Biochem Biophys Res Commun 2003:302:575-80.

14 Stehlik C, Lee SH, Dorfleutner A, Stassinopoulos A, Sagara J, Reed JC. Apoptosis-associated speck-like protein containing a caspase recruitment domain is a regulator of procaspase-1 activation. $J$ Immunol 2003;171:6154-63.

15 Agostini L, Martinon F, Burns K, McDermott MF, Hawkins PN, Tschopp J. NALP3 forms an IL-1 beta-processing inflammasome with increased activity in Muckle-Wells autoinflammatory disorder. Immunity 2004;20:319-25.

16 Stehlik C, Fiorentino L, Dorfleutner A, Bruey JM, Ariza EM, Sagara J, et al. The PAAD/PYRIN-family protein ASC is a dual regulator of a conserved step in nuclear factor kappaB activation pathways. J Exp Med 2002; 196:1605-15.

17 Dowds TA, Masumoto J, Zhu L, Inohara N, Nunez G. Cryopyrin induced IL-1 secretion in monocytic cells: enhanced activity of disease-associated mutants and requirement for ASC. J Biol Chem 2004;279:21924-8.

18 Martinon F, Burns K, Tschopp J. The inflammasome: a molecular platform triggering activation of inflammatory caspases and processing of proll-beta. Mol Cell 2002;10:417-26.

19 Grenier JM, Wang L, Manji GA, Huang WJ, Al-Garawi A, Kelly R, et al. Functional screening of five PYPAF family members identifies PYPAF5 as a novel regulator of NF-kappaB and caspase-1. FEBS Lett 2002;530:73-8.

20 Masumoto J, Dowds TA, Schaner P, Chen FF, Ogura Y, Li M, et al. ASC is an activating adaptor for NF-kappa B and caspase-8-dependent apoptosis. Biochem Biophys Res Commun 2003;303:69-73.

21 McDermott MF. Genetic clues to understanding periodic fevers, and possible therapies. Trends Mol Med 2002:8:550-4.

22 Tidow N, Chen X, Muller C, Kawano S, Gombart AF, Fischel-Ghodsian N, et al. Hematopoietic-specific expression of MEFV, the gene mutated in familial Mediterranean fever, and subcellular localization of its corresponding protein pyrin. Blood 2000;95:1451-5.

23 Masumoto J, Taniguchi S, Nakayama J, Shiohara M, Hidaka E, Katsuyama T, et al. Expression of apoptosis-associated speck-like protein containing a caspase recruitment domain, a pyrin $\mathrm{N}$-terminal homology domaincontaining protein, in normal human tissues. J Histochem Cytochem 2001;49:1269-75.
24 Boyle DL, Rosengren S, Bugbee W, Kavanaugh A, Firestein GS. Quantitative biomarker analysis of synovial gene expression by real-time PCR. Arthritis Res Ther 2003;5:R352-60.

25 Yamanishi Y, Boyle DL, Rosengren S, Green DR, Zvaifler NJ, Firestein GS. Regional analysis of p53 mutations in rheumatoid arthritis synovium. Proc Natl Acad Sci USA 2002;99:10025-30.

26 Alvaro-Gracia JM, Zvaifler NJ, Brown CB, Kaushansky K, Firestein GS Cytokines in chronic inflammatory arthritis. VI. Analysis of the synovial cells involved in granulocyte-macrophage colony-stimulating factor production and gene expression in rheumatoid arthritis and its regulation by IL-1 and tumor necrosis factor-alpha. J Immunol 1991;146:3365-71.

27 Young DA, Lowe LD, Clark SC. Comparison of the effects of IL-3, granulocytemacrophage colony-stimulating factor, and macrophage colony-stimulating factor in supporting monocyte differentiation in culture. Analysis of macrophage antibody-dependent cellular cytotoxicity. J Immunol 1990;145:607-15

28 Firestein GS, Paine MM. Stromelysin and tissue inhibitor of metalloproteinases gene expression in rheumatoid arthritis synovium. Am J Pathol 1992;140:1309-14.

$29 \mathrm{CIAS1/cryopyrin/PYPAF1/NALP3/CATERPILLER} 1.1$ is an inducible inflammatory mediator with NF-kappaB suppressive properties. J Immunol 2003;171:6329-33.

30 Firestein GS, Zvaifler NJ. How important are T cells in chronic rheumatoid synovitis? : II, T cell-independent mechanisms from beginning to end. Arthritis Rheum 2002:46:298-308.

31 Hull KM, Shoham N, Chae JJ, Aksentijevich I, Kastner DL. The expanding spectrum of systemic autoinflammatory disorders and their rheumatic manifestations. Curr Opin Rheumatol 2003;15:61-9.

32 Matzner Y, Abedat S, Shapiro E, Eisenberg S, Bar-Gil-Shitrit A, Stepensky P, et al. Expression of the familial Mediterranean fever gene and activity of the $\mathrm{C} 5 \mathrm{a}$ inhibitor in human primary fibroblast cultures. Blood 2000:96:727-31.

33 Diaz A, Richards N, Schaner P, Gumucio D. Expression of alternatively spliced forms of pyrin in human leukocytes and synovial fibroblasts [abstract]. Clin Exp Rheumatol 2002;20(suppl 26):S82.

34 Chae JJ, Komarow HD, Cheng J, Wood G, Raben N, Liu PP, et al. Targeted disruption of pyrin, the FMF protein, causes heightened sensitivity to endotoxin and a defect in macrophage apoptosis. Mol Cell 2003;11:591-604.

35 Harton JA, Linhoff MW, Zhang J, Ting JP. Cutting edge: CATERPILLER: a large family of mammalian genes containing CARD, pyrin, nucleotide-binding, and leucine-rich repeat domains. J Immunol 2002;169:4088-93. 